\title{
A Geo-Environmental Assessment of Flood Dynamics in Lower Ajoy River Inducing Sand Splay Problem in Eastern India Sutapa Mukhopadhyay
}

\begin{abstract}
:
Flood as a widespread destructive natural disaster is recurring in the river basins of Eastern India. Though large number of flood controlling measures have been taken in the river valleys from the early ages but it is to be noted that spatial dimension of the flood affected area and the magnitude of flood are being increased significantly year by year. The present alleviation measures are seemed to give false security to the bank dwellers. Once to protect the agricultural fields and the settlements embankments were constructed along both sides of the rivers but now the hydrologists feel that those human interventions have changed the character of the river regime. Consequent effect of it is the breaching of the embankments and the occurrences of sand splay over a massive area. Studies have made here in one of the important flood prone river basins of Eastern India, i.e. Ajoy, where the rate of sand splay formation has significantly hastened many times and it has a negative effect on the fertility of the agricultural fields. Some structural and non-structural measures have been suggested on the basis of the field observation.
\end{abstract}

\section{Introduction:}

Ploods are arguably one of the most
universally experienced and damaging surface hydrologic phenomena in the geosphere. They tend to be larger in spatial impact and bear an immense socio-economic and political significance in places frequented by this process. Of all types of floods, riverine floods appear to be the most common and dominant occurrence with significant effects on the surrounding environment, both physical and cultural (Ward, 1978). Floods are caused by variety of factors, not all of them are weather induced. Topography and hydrological capacity of the subsoil and failure of flood protection structure are the other critical factors in this regard. In the present scenario of worldwide development environment conflict, ecological disturbances like deforestation and flood plain encroachment by human activities have increased the frequency and intensity of floods indicating that no country is free from severe flood hazards.

Flood is undoubtedly the most dreadful natural calamity of Eastern India where it becomes almost an annual phenomenon. The worst affected state of this part of India is West Bengal where 55.43 percent of total geographical area is flood prone. According to the Government report 2000, the most remarkable flood year, about 2.21 crores of population were affected and the total estimated loss was Rs $5,660.65$ crores. It is important to note that spatial dimension of the flood affected area is being increased significantly and the damages they render are pervasive and long term.

From the early ages large number of flood controlling measures have been taken in the river valleys of Eastern India but now a days people feel that human intervention in the river valley have changed the hydrological regime of the rivers of South Bengal and these may be the cause of the flood related disasters of Bengal. The present alleviation measures like the increase of the height of the embankment, repairing of embankment, aforestation in the upper catchment, adopted by the local governments turns into failure and it seems to give a false security to the bank dwellers. Sir William Wilcox (1930) accused the riverside embankments as satanic chains and proposed canal for draining out the floodwater. Prof M.N.Saha (1935) was also concerned about the effect of embankments on the hydrological character of the rivers while explaining the causes of the flood of Bengal, Mr. S.C. Majumbar (1945), the eminent engineer warned about the long term effect of embankment and stated " construction of embankment as flood controlling measures would be like mortgaging the future generations to derive some temporary benefits for the present generation". But it is irony that still at the present $21^{\text {st }}$ century dams and embankments are considered as flood relieving measures, often these are designed abysmally poor knowledge of the hydrological character of the rivers (Pearce, 2001). So we cannot reduce the new genre of flood hazards by frequent breaching of embankments. Sand splay is one such effect of it, which have great effect on the economy of the riverside villages. Sands play is the deep sheet of sand deposited at the back swamp areas due to sudden break of river embankment and ejection of sand from the riverbed all of a sudden. Once a time when 
human being was far from the active back swamp areas, such occurrences were no problem at all. But due to massive encroachment of human being to the interior of this region, the sand splay is bringing lots of problem in connection with ecohydrology and economy. Moreover the rate of sand splay formation has been hastened many times due to significant growth of manmade flash flood. Today the rate of sand splay formation is so rapid and its effect is so much in both short and long term is defined as disaster. This phenomenon is not only responsible for spreading of sand to the agricultural lands and back swamp areas but also acutely responsible for negative change of soil fertility, ecohydrology of the basin etc.

With this back ground in this article the study has been done on the changing flood character of river Ajoy, one of the important flood prone river basins of West Bengal state of Eastern India, since last fifty years and the extended nature of sand splay as a post flood geomorphological hazard along the river.

\section{The Geographical and Administrative} Acquaintance

The river Ajoy is a right bank tributary of the Bhagirathi River, one of the major distributaries of the Ganga. From the source region at Chakai to the confluence at Katwa, the river Ajoy is passing through three major geological set up. From the source region to about $190 \mathrm{kms}$ downstream at Jamtara it flows over Archaean gneissic complex, then it is on Gondwana sedimentary rocks for $30 \mathrm{~km}$ up to Pandabeswar and for rest it flows over older and recent alluvial deposits. The total area of the Ajoy river basin is $6,221 \mathrm{sq} \mathrm{km}$. The average slope of the basin is 1 in 750 from source region to Pandabeswar and from Pandabeswar downwards the slope drops to about 1 in 2,250. The lower Ajoy river basin has been demarcated from Pandabeswar as there is a significant break along the long profile of the river slope. So following $80 \mathrm{~m}$. contour line, as the break of slope point, the upper limit of the lower Ajoy basin has been demarcated. The river flows over the flat surface that supports the oscillation of the channel, sluggish flow, low bank height and low velocity. The river trickles through the sand bed from the month of November to mid June and becomes a subject to a sudden freshet at the onset of Monsoon. As the flood rarely occurs at the upper catchment so the present discussion is mainly at the lower stretch of the Ajoy river basin. The length of the river of this part is $145 \mathrm{kms}$ and the total basin area of this lower stretch is $2,816.65 \mathrm{sq}$. $\mathrm{km}$. The whole basin latitudinally extends from $23^{0} 25^{\prime}$ North to $23^{\circ} 45^{\prime}$ North and longitudinally between $87^{0} 20^{\prime}$ East to $88^{\circ}$ East. The important settlements like Pandebeswar, Illambazer, Kanska, Bolpur -Santiniketan, Guskara, Natunhat, Mangalhat, Ketugram, Katwa have taken shape in the basin over decades (fig 1). There are 619 mouzas (small administrative unit), under $12 \mathrm{CD}$ Block (Community Development Block) located in the said basin area. It is estimated that out of the total mouzas about 493 are flood affected entirely or partially, which is about $79.65 \%$ of the total.

\section{Physical Background of the area}

The whole river basin has been designated from the elevation range of $80 \mathrm{~m}$ in the west to $14 \mathrm{~m}$ above sea level in the east (fig 2). The physiographic set up of this basin area is characterised by two major units viz. i) the badland with lateritic hard crust zone of the western part of the basin area where the level of lateritic landscape is modified by the gully actions. This undulated land occupies about $37.05 \%$ of the total area and is covered by brown clay with scattered forest cover. ii) the fluvial aggradational landform occupies the rest $62.95 \%$ of the total area where natural levees, flood plains, sand splay, alluvial terraces, sand bars are the dominant features. Below $40 \mathrm{~m}$ contour, just from the eastern flank of the lateritic hard crust there is almost flat surface where meandering nature with large shoal deposits are common along the river course.

On the basis of the slope and other morphological attributes four altitudinal zones have been demarcated in the lower Ajoy basin

i) Western plain $(80 \mathrm{~m}$ to $60 \mathrm{~m})$ : The region covers the laterite upland on the Gondwana rocks in the eastern part of the Raniganj coalfield. It occupies about 46,623.29 hectares that is $16.55 \%$ of the total lower basin area.

ii) Western Central plain (60 m to $40 \mathrm{~m}$ ): It lies in between the eastward extending part of lateritic upland and older valleys of the river system.

iii) Central Plain (40m to $20 \mathrm{~m}$ ): It has an area of $10,19,63.04$ hectares or $36.20 \%$ of the total area. It bears the lowest quaternary alleviation and younger alluvial silts in the eastern part. 


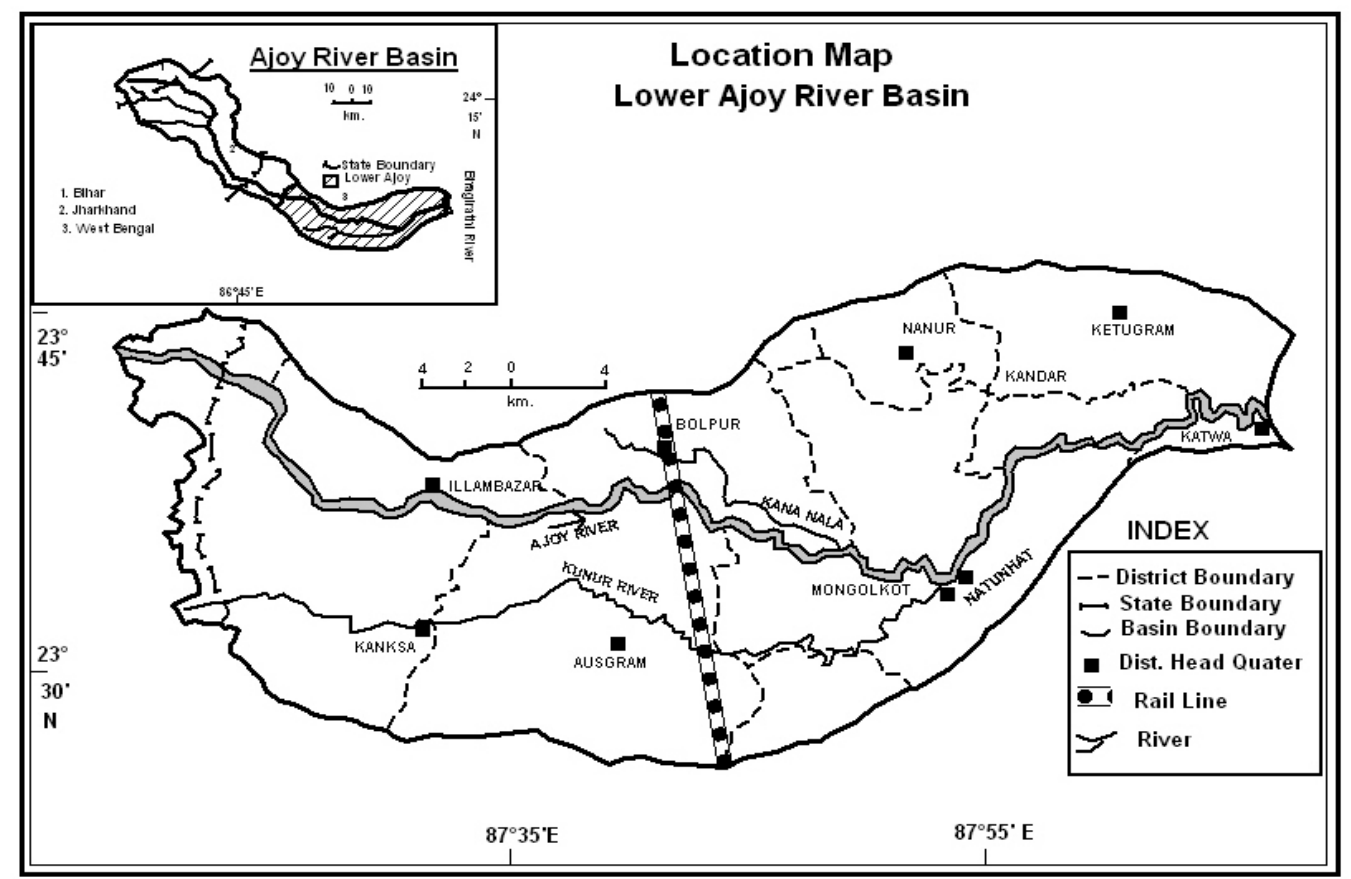

Fig. 1Location map of Lower Ajoy River Basin,India

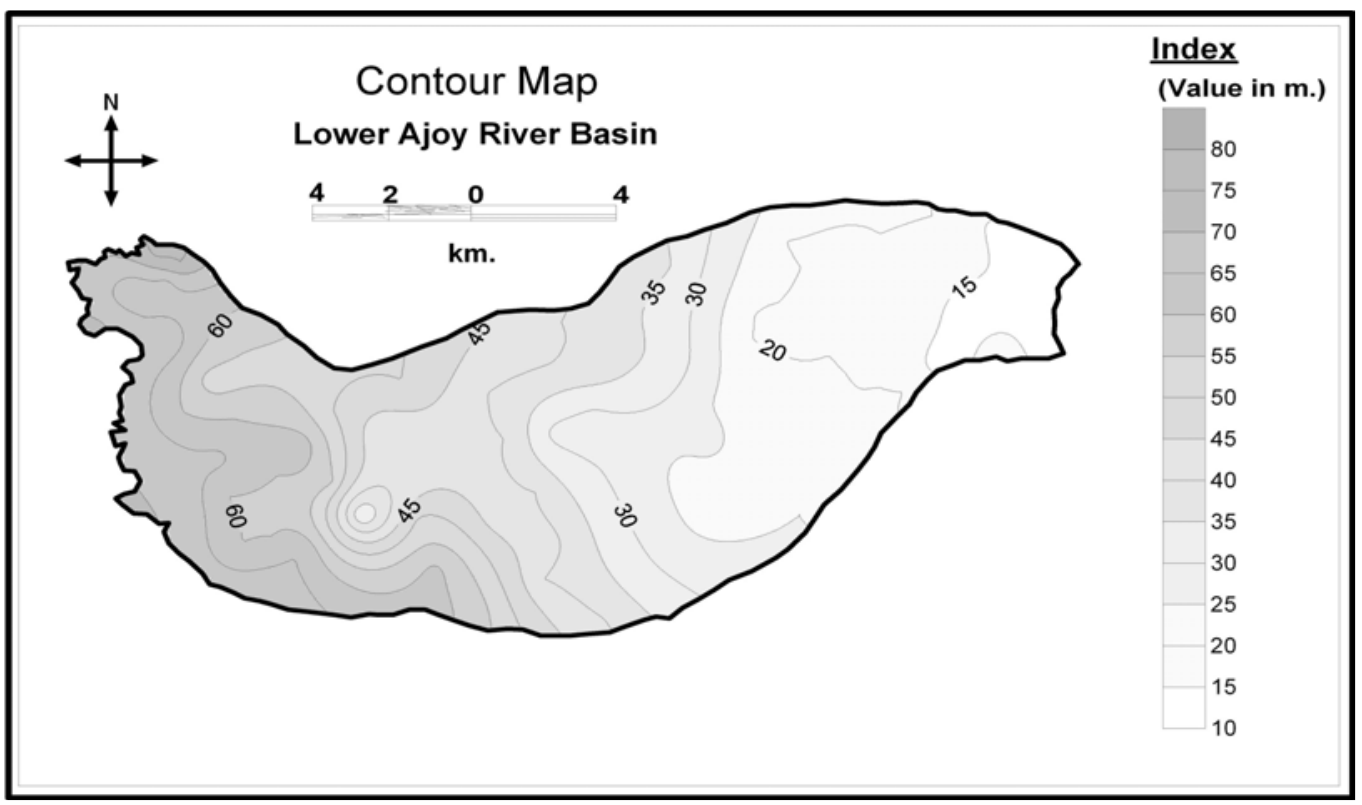

Fig. 2 Contour Map of Lower Ajoy River Basin, India

iv) Eastern plain (Less than 20m) : It is characterised by the new flood plain, channel deposits and some scattered marshy lands of eastern flank of the Ajoy - Bhagirathi system.

Average slope of the Ajoy River basin area is 1 in 750 from source point to Pandabeswar and over this lower stretch the slope drops down to about 1 in 2250, i.e. from Pandabeswar to confluence point. Due to the construction of embankments along both the banks the width of the channel varies along its long stretch. In this long stretch of lower catchment area sub parallel drainage predominates over the subdendritic pattern and to some extent braided pattern is formed at many parts.

The shape of the basin is funnel like where huge volume of water from upper 
catchment flows through a restricted narrow channel in the lower catchment and it causes flood. The Hinglo and Kunur are the major sub basins of river Ajoy over this stretch. The Hinglo sub basin is characterised by low drainage density $(1.25 / \mathrm{sq} \mathrm{km})$, which suggests that the catchment area is constituted by such rocks like granite and gneiss, which permits more infiltration of the surface runoff. The bifurcation ratio is moderately high suggesting erosive nature of the sub basin. A drainage density of 0.85 per sq $\mathrm{kms}$, which indicates that the catchment area has more infiltration capacity, characterizes the Kunur sub basin. High bifurcation ratio also indicates high erosive nature of the sub basin.

As the general gradient of the basin area in from northwest to south/south east so the embankments have mainly constructed along the right bank of the river up to Bhedia. These embankments have also checked the river widening processes in the lower courses. This gradual constricted flow of the river in downward course has vital role in the occurrences of flood over the area.

Mean annual discharge of the river is 65.46 cumecs at Natunhat, which is $45 \mathrm{~km}$ above from the confluence and it rises to about 247.95 cumecs in the month of August and again declines to about 1 cumec in March \& April. During summer month rainfall merely exceeds $100 \mathrm{~mm}$ and it is even over $1500 \mathrm{~mm}$ during rainy months. Therefore sudden outburst of monsoon or local cyclonic depression over Bay of Bengal and the Gangetic West Bengal during the month of September \& early October is one of most important causes of flood in the lower Ajoy basin area. It is to be noted that almost all devastating floods of the Ajoy river have occurred in the month of September when heavy rainfall occurs in a couple of days.

The land use pattern of an area in highly altered by the annual flood. Broadly it can be said that this lower basin area consists highly productive land (fig 3 ). It is estimated that $62.58 \%$ of the total land is used for cultivation of which $40.27 \%$ is irrigated and $22.31 \%$ is non-irrigated. The area lying below $40 \mathrm{mt}$ contour line has network of irrigation canals, tanks and tube wells. Forested land occupies only $13.17 \%$ of the total land and the concentration is more in the right bank than the left bank. On the other hand about 1.77 percent of land is occupied by cultivable waste, these are mainly found in the river astride sand covered part (Table 1). Generally during flood, fine grained newer alluvium deposited over the land and increase the productivity of the soil. So the extensive fertile multiple cropping land is prominent along the right bank of the river below Bhedia. However devastating floods of 1978, 1985, $1999 \&$ 2000,2005 and 2007 have dramatically changed the agricultural lands into cultivable wastelands. The sand deposition with an average depth of $50 \mathrm{~cm}$ to $1 \mathrm{mt}$ over fertile cultivable lands has converted the land into sandy wasteland. In this river basin area about 700.15 hectares of good cultivated land have been lost due to sand splay where the farmers are not in a position to cultivate their principal crops like paddy, wheat, potatoes etc. Historical overview on the floods of Ajoy river

The lower Ajoy river basin has been suffering from floods since time immemorial. The evidence of flood in the form of yellowish and whitish sandy silt layer has been traced even in the river astride archeological sites that dates back to more than two millennium B.C. Ajoy river was navigable for those years and had great commercial significance some thousand years back. Villages along the river like Supur, Raypur, Illambazar, Karimpur, Katwa etc were once important trading centres. But these settlements have lost their significance due to the changing of the river regime. During $18^{\text {th }} \& 19^{\text {th }}$ century normal flood had occurred which resulted the formation of flood plain as there was no embankment in those days. A huge volume of water was flowing through the river of sufficient depth. The river had a tendency to shift its course and as a result a flood plain had extended to a large extent of area.

During British period in $19^{\text {th }}$ century recorded major floods were in 1867, 1877, 1885 \& 1896. After that unusual high flood occurred in 1913, 1914 causing serious loss of life and property, damage to standing crops, seeds and houses. The English district officer took immediate steps to help the people, suspension of revenue collection was ordered in all the flood-affected areas. In the nineteenth century some embankments were scatteredly constructed by the then zamindars and was not technically 
maintained. During zamindary period silt and clay laden floodwater have brought into the agricultural field by cutting of embankment for maintaining natural fertility. But now the flood magnitudes and damages have severe effect on the dwellers especially at the breaching point of the embankments.

\section{Temporal flood character}

A significant

changing

characteristic has noticed from the flood data analysis since the last half of nineteenth century (Table 2). The major recorded flood years are 1956, 1959, 1970, 1971, 1973, 1978, 1984, 1995, 1999, 2000, 2005, and 2007. Among these most devastating flood years are 1978, 1995, 1999 and 2000. Frequent floods are generally observed below Illambazar particularly after the confluence point of the Hinglo river, which is used to suffer in almost all flood year.

Spatial extent of flood:

The extent of flood in some major flood years is confined along the river astride areas of the basin particularly from the downstream of Pandabeswar to the area up to Illambazar in the left and Basudha in the right bank. The flooded area is suddenly spreaded in the right bank in the east of Illambazar - Panagarh high way. The Bolpur - Natunhat highway, demarcates the last extension of major floods in the left bank. Map of flood affected area of phase I and phase II (fig 4 $\&$ 5) have shown the nature of flood spreading in different blocks of the basin. Generally it has been observed that maximum area spreaded during the flood year of 1978, 1995, 1999, 2000, 2007. The flood is confined along the narrow strip area of the two banks in the western part of the basin area, particularly in the blocks of Dubrajpur \& Illambazar in the Birbhum district and Kanksa of Burdwan district. The areas below Illambazar in the right bank and downstream Bolpur in both the bank the floods of all major years have spreaded vastly. The number of floodaffected mouzas is more in the right bank than the left bank. In 1956 the flood affected mouzas were 93 in the right bank and the left bank accounts for 72. In 1970 it is estimated that in total 221 affected mouzas there were 121 on the right and
101 on the left bank. But gradually the flood area has also been extended in the left bank and the differences in the number of affected mouzas between two banks are being reduced. In the flood year 2000 about 187 mouzas were affected on the right bank and 182 were on the left bank, even in the year 2007 out of total 293 affected villages about 150 mouzas were in right bank and about 143 on the left bank.

From the locational analysis of flood frequency it can be concluded that flood proneness increases abruptly from Satkahania down ward. Above this station at the upper reaches of the basin there are 17 occurrences at Beta and 25 at Satkahania but from this station downward there is a steady increase of number of occurrences. It is 39 at Maliara, 47 at Gheropara and 40 at Natunhat, which are the most vulnerable points on the flood map of Ajoy river (see table 3).

\section{Monthly flood variation}

As a rain fed river the discharges of the Ajoy increases from the month of June due to huge Monsoonal rain and it generally lasts up to the month of September and then falls down. So the State irrigation and Water ways Department begins to record flood level from the month of June in each year and continues up to the month of October. Table 4 shows the monthly flow level pattern of three gauge stations of mostly dominated flood affected parts of the basin (Table 4). The table 4 revealed some relevant facts -All the highest flood level of each flood year is recorded in the month September. The flood flow from June to September has been increased steadily but the sharp rising trend is noticed from the month of August to September in the noted flood year i.e. 1970, 1978, 1995, 1999, 2000, and 2007.

It is worthy to mention that the recorded discharge of 1978 was the highest level in the last century but the peak flow of September 2000 is almost equal to that mark of 1978.

The temporal changing pattern of the floodaffected areas has been tabulated below since 1956. The percentage of area and the number of affected mouzas are gradually being increased. Notable flood covered areas are observed in 1970, 1978, 1995, 1999, 2000, 2007. 
The highest flood level of different gauge stations have been formulated in Table 3. The danger levels of Beta, Satkahani are of much high i.e. $57.90 \mathrm{mt}$ and $51.75 \mathrm{mt}$. respectively. But further downward at Gheropara the height is $39.41 \mathrm{mt}$ and at Natunhat it $19.19 \mathrm{mt}$. The increasing volume of water and decreasing slope are the major factors for such variation. The correlation efficient determination value 0.917 clearly indicates highly positive relation between the floods affected areas and number of affected mouzas and there is an increasing tendency of both of them (fig 6). During the flood year the peak flow level of each gauge station crosses the danger level. Among them at Maliara and Gheropara the flood level flows about 2 to $3 \mathrm{mt}$ above danger level (Table 3). So this middle stretch of basin area is the vulnerable area for flood occurrences. This view is well supported by the flood affected zonation map of the basin and the former results of flood level exceed frequency (fig $7 \&$ Table 1 ).

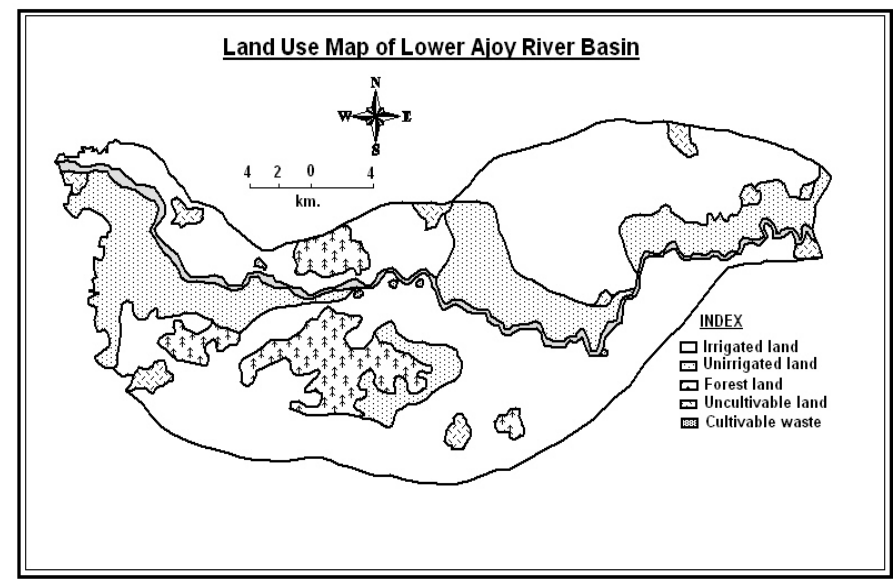

Fig. 3 Land Use Map of Lower Ajoy River Basin, India

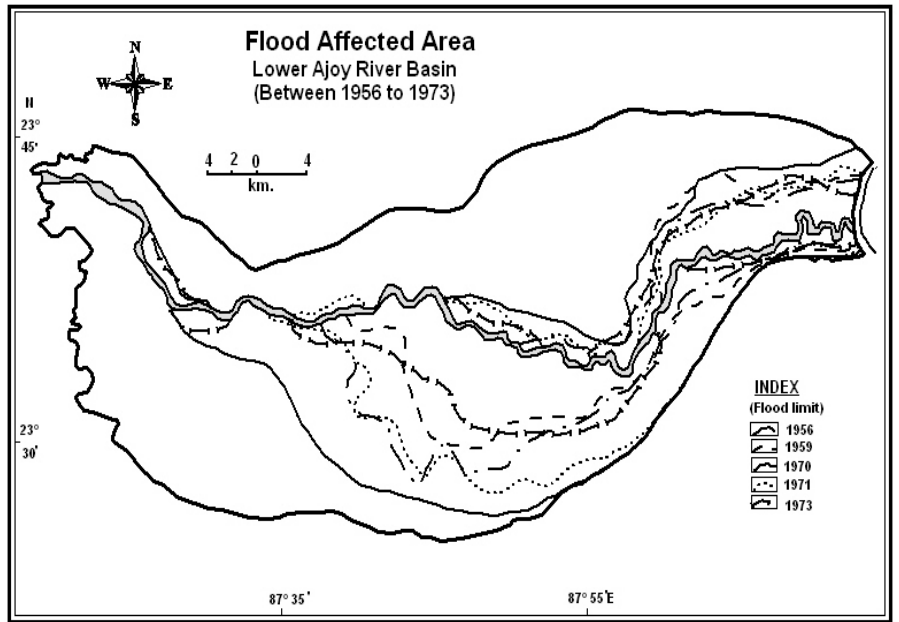

Fig. 4 Flood affected area Lower Ajoy River Basin, India 1956-1973 


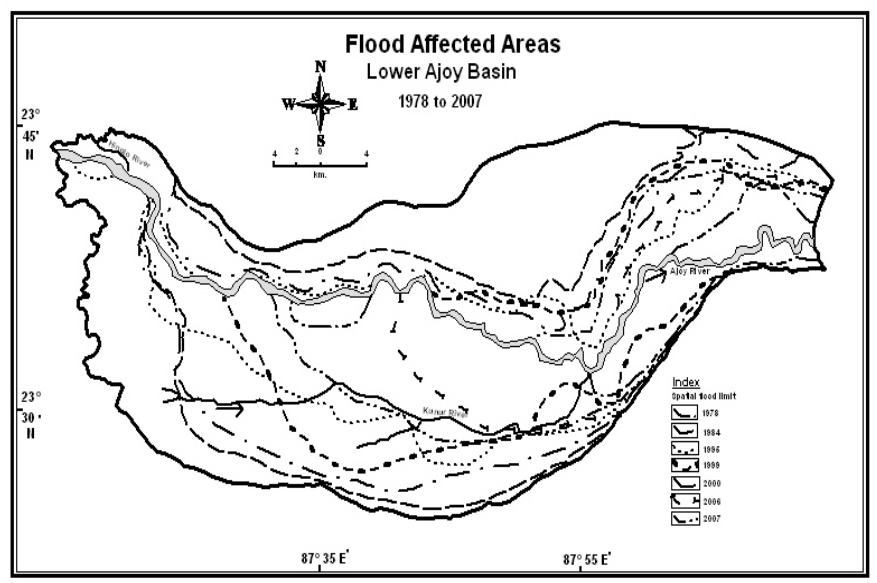

Fig. 5 Flood affectes area Lower Ajoy River Basin, India1978-2007

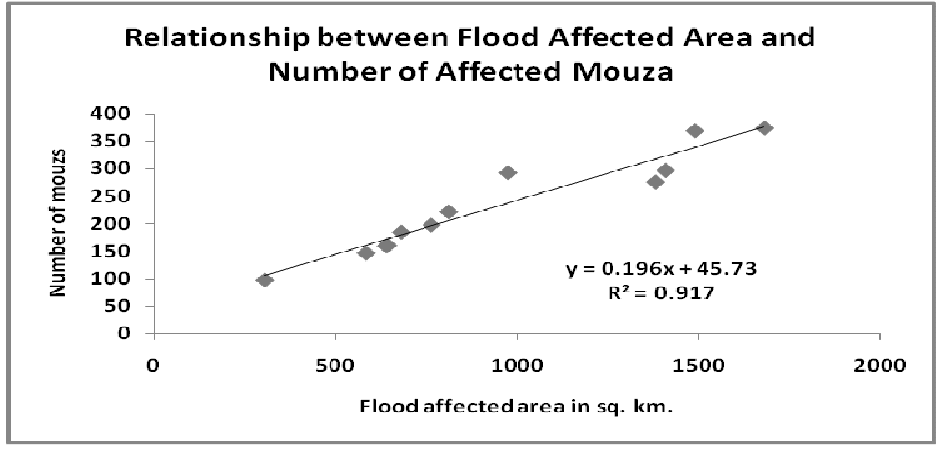

Fig. 6 Flood affected area and number affected

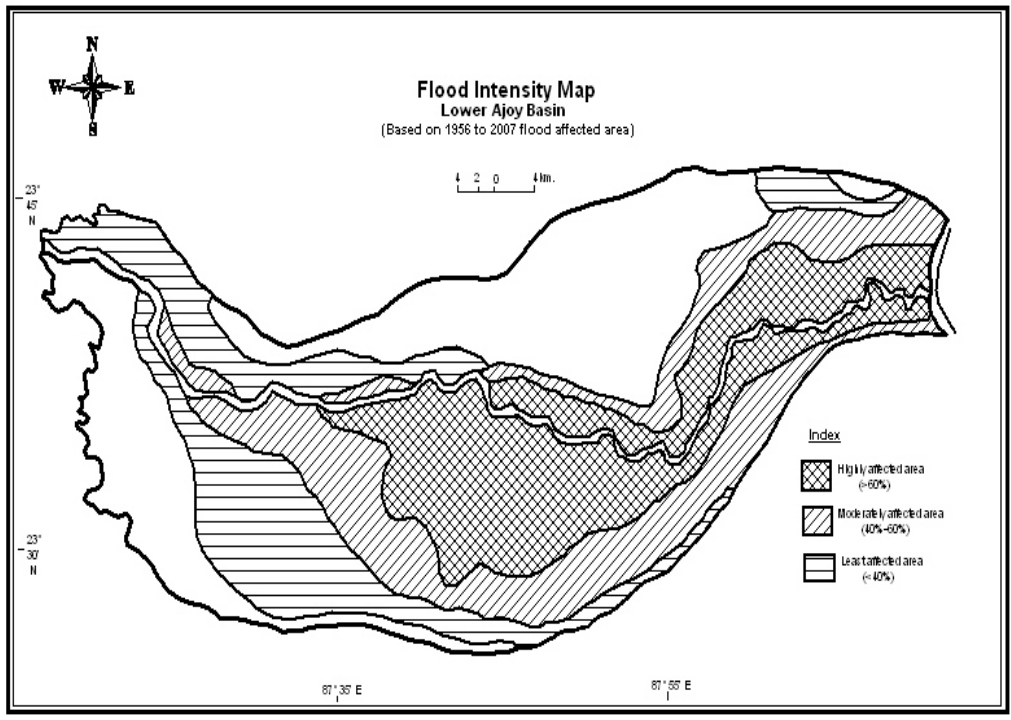

Fig. 7 Flood intensity Map 
The correlation graphs (fig. 8 \& fig. 9) have shown a positive relation between the flood height of the gauge station and the flood affected areas. But the coefficient of determination value is not significant (0.374) at Maliara where the slope of the land surface is a major determinant factor. The $\mathrm{R}^{2}$ value is 0.496 at Natunhat, which indicates moderately significant relationship.

\section{Causes of flood}

So many physical and human induced factors are responsible for such kind of occurrences. The short period massive rainfall is the main cause of such problem. Out of total rainfall almost $85 \%$ rainfall occurred within 3 to 4 monsoon months of the year. About 60 to $70 \%$ rainfall was happened within very short period of time i.e. 3-4 days during 1956, 1970, 1973, 1978, 1999, 2000, 2005. Another two factors that aggravate the flood situation in the above-mentioned areas are sudden decrease of river width particularly below Bhedia and the synchronization of the water level between river Ajay and river Bhagirathi. Other related physical factors are the long, narrow shape of the river basin, gentle longitudinal gradient of the river-all of which favour the situation of riverbed siltation and reduction of river load capacity (Mukhopadhyay \& Mukherjee 2005).

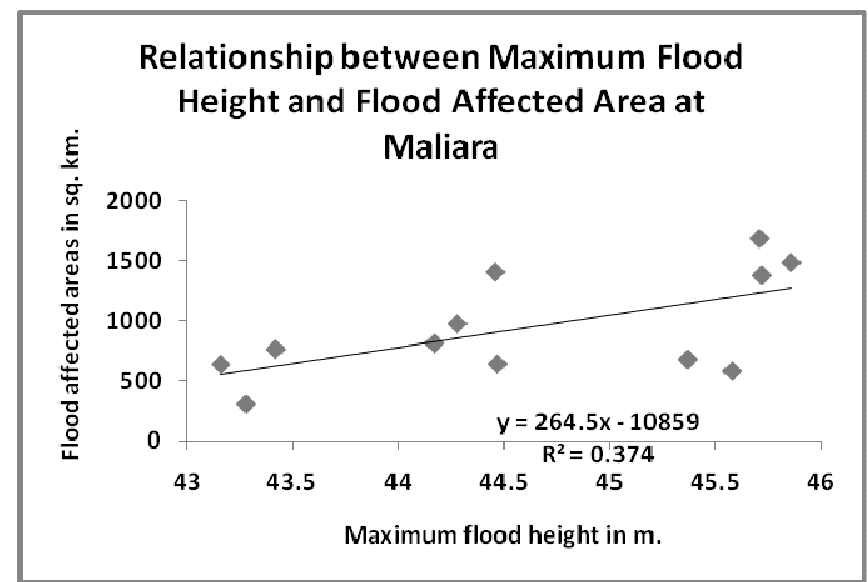

Fig. 8 Flood height and Flood Affected Areas at Maliara

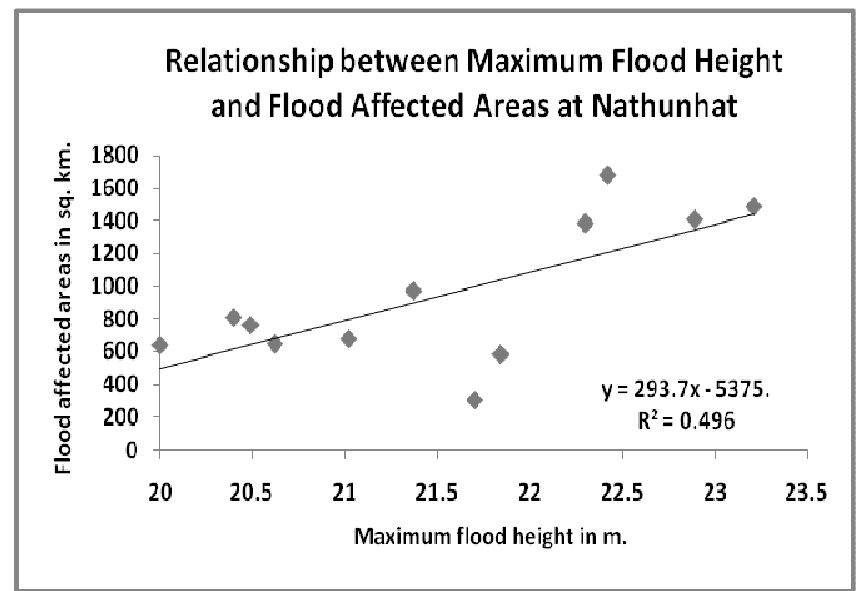

Fig. 9 Flood height and Flood Affected Areas at Nathunhat 
Among some anthropogenic factors of flood the presence of the earthen embankments along both sides of the river cannot be ignored. To protect the fertile agricultural land and number of prospectus settlement Zamindari bundhs (embankment) were constructed and later these were transferred to Irrigation and Waterways Department, Govt. of West Bengal, after the flood of 1959 for maintenance and reconstruction. These embankments entrap the river and interestingly the width of the river gradually decreases downwards. Consequently, along with massive downpour, sudden release of water from Hinglo barrage upstream triggers the breaching of embankment. During peak discharge period there is well marked fluctuation found in between the two gauge stations as the floodwater passed out through those breaching points (Mukhopadhyay \& Mukherjee, 2005).

As per general system of river the widths gradually increase toward downstream. But due to the construction of embankment it is interestingly noted that at the upstream points like Pandabaswar ( $\left.23^{\circ} 44^{\prime} \mathrm{N}, 87^{\circ} 17^{\prime} \mathrm{E}\right), \quad$ Palashdanga $\left(23^{\circ} 43^{\prime} \mathrm{N}, 87^{\circ} 23^{\prime} \mathrm{E}\right)$ widths of the river are significantly more $(1010 \mathrm{~m}$. and $1225 \mathrm{~m}$.) but at down stream near Kogram $\left(23^{\circ} 33^{\prime} \mathrm{N}, 87^{\circ} 57^{\prime} \mathrm{E}\right)$ it becomes narrower about $125 \mathrm{~m}$ and at the confluence point Katwa it is only $230 \mathrm{~m}$. So such saucer shape river course is predominantly convicted for the slow water movement and inundation in the lower course.

\section{Breaching of embankments \& occurrence of sands play}

Due to lack of proper construction and maintenance breaching occurred in the outer head of the meander of the river. Unfortunately, the villages were located near those points now have been wiped out from the map due to strong invasiveness of the flood current. The number of breaching points is rapidly increasing toward downstream. It has been observed that from Joydev to Bhedia the breaching tendency is more in the right bank and Bhedia to Narenga the breaching tendency is more in the left bank. The most prominent effect of the breaching of embankment and the occurrences of the flood is the sand splay as post flood hazard (fig10). This fact is quite well illustrated by the Table 5 where sand splay occurrences are much more along the right bank of the river.

Due to little slope differences along the lower course particularly below Illambazar, rate of siltation is very high which decrease the water accommodating capacity of the river. In addition to this, more meandering nature of the river, varying width of both sides embankment and high discharge of water from the Hinglo barrage during peak flow period, cause breaching of embankment in the left and right bank respectively. It has been recorded that embankments breach at 12 places in 1978 and in 1999 the number was 22 whereas in 2000 it reached to 25 . Though the large-scale sand splay had occurred after 1978's flood but it exceeded the previous record during the flood year 1999, 2000.

Table 2 depicts the fact that the extent of sand splay area is also being increased. More than 1000 hectare of land is affected by sand splay in the flood year 1973, 1978, 1995, 1999, 2000, 2006, 2007. It is also interesting that the spatial extension of sand splay areas have been gradually increasing far from the river embankment so each and every year new areas are included within the flood domain areas. In the flood year 2000 about 1678.90 hectare new lands has added as sand laden area. The total amount of flood induced sand covered land of 1959 was 231.45 hectare, even in 1970-71 it was within 800 hectares. But since 1999 the sand covered area has increased to more than 2500 hectares.

\section{Textural pattern of the sand splay}

The sand splay has changed the micro topographical pattern of the flood plain. A cross sectional profile has drawn (fig 11) at Maliara, one of the important embankment beaching point, to make a comparison between the former and present land configuration (Mukherjee 2003). The depth of sand cover is about 20 $\mathrm{cm}$ near to the river but just after crossing the embankment landward the depth has increased to $1.5 \mathrm{mt}$ and gradually the depth decreases with distance. It is also noticed that $90 \%$ of the sand ranges from $1.00 \mathrm{~mm}$ to 106 micron. 


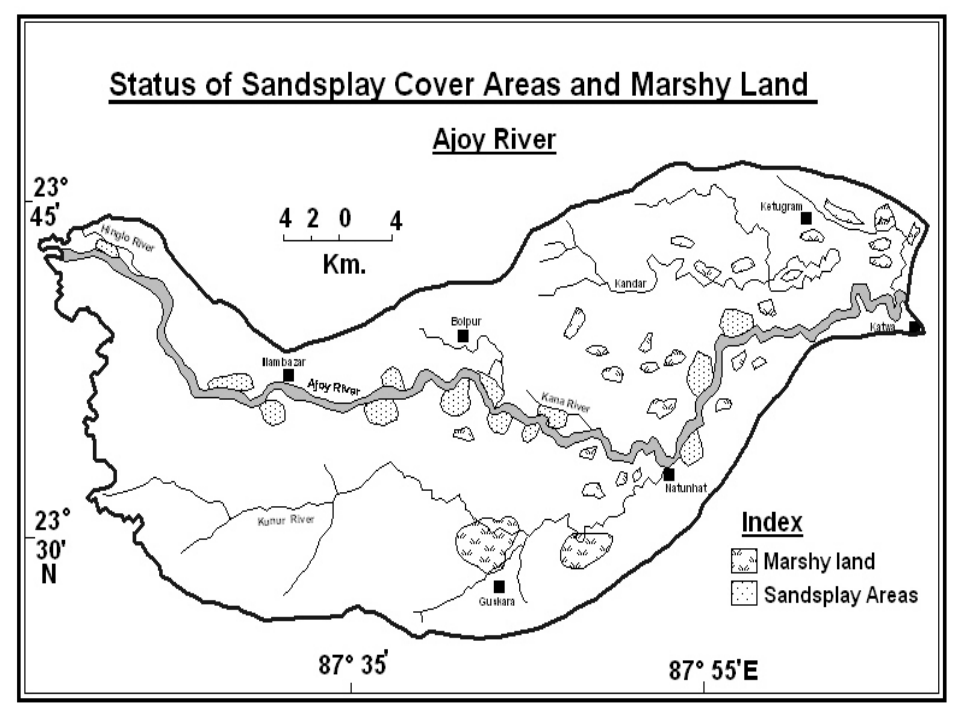

Fig. 10 Status of sand splay cover area and marshy land

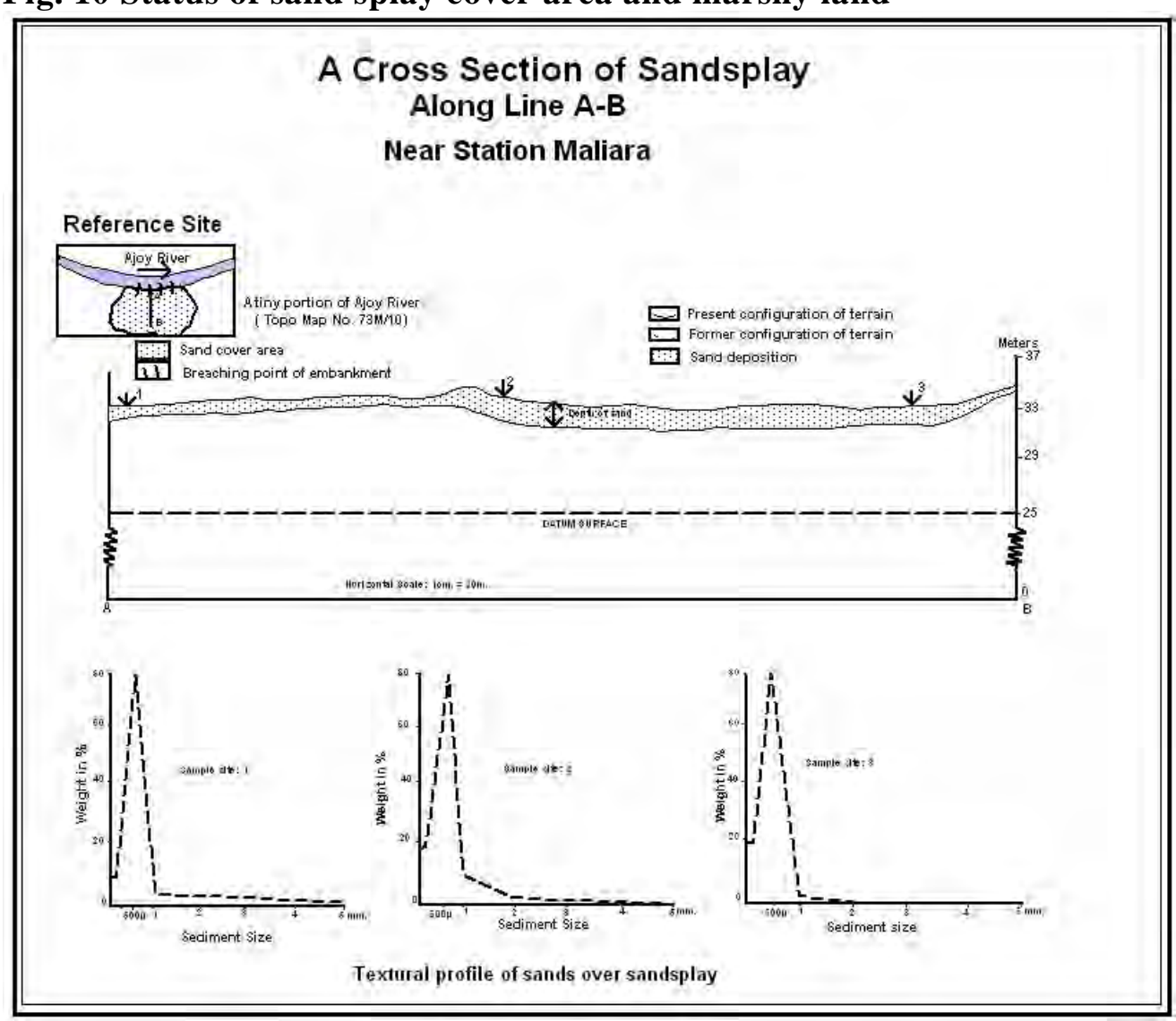

Fig. 11 Cross section of sandsplay

Moreover the slight amount (nearly to $1.5 \%)$ of coarse sediments can be marked near the breaching point due to sudden flash of water but gradually becomes finer as moving apart. 


\section{Relation between flood extension and sand splay}

Table 2 has shown that the flood affected area as well as the sand splay lands are gradually extending simultaneously through out the basin since early ages, though there is abrupt increase of affected lands from the flood year 1999. Along with the heavy rainfall gradual decreasing of the water holding capacity of the river due to siltation may be considered as the prime factor of such extension.

There is also a positive relation (fig 12) between flood affected area and sand splay cover area but the coefficient value 0.622 denotes the moderate relationship as the extension of sand splay depends upon the number of breaching points of the embankment along with the amount of downpour.

Though the magnitude of flood is gradually increasing and side by side nature of damages are being changed significantly but if the embankment would breach before any gauge stations then the maximum flood height level drops suddenly and recorded level does not indicate the actual flood level of the station. So the relationship between the flood height of the gauge station and sand splay extension is not significant i.e. $\mathrm{R}^{2}=$ 0.430 (fig 13).

Impact of Sand splay:
Sand splay cover area is increasing in very rapid rate which entails lots of associated problems related to physical and chemical quality of soil, agricultural activities, agricultural production, productivity, quantitative and qualitative degradation of agricultural land etc. Some crudely infested problems associated with sand splay are:

\section{Loss of Cultivated Land}

Cultivated land loss is highly significant in twenty mouzas, among them some mouzas namely Haripur, Natungram, Srikrishnapur, Bira etc. are so infested, agricultural land use system has totally destroyed (Table 6). Fertile rice field has buried under thick sterile sand sheet. The areas claded by sand are now totally out of cultivation. This kind of problem diminishes the agricultural status of the region as well as economic backbone.

The areas marginally affected by sand cover, but do not have refused the production entirely, the production quality has reduced in massive scale. On an average productivity of kharif (rice) crop has reduced about 3 to 5 times (Table 7 ). Severe sand cover areas today totally out of production.

\section{Degradation of Soil Quality}

Standard soil quality is one of the important parameter for agricultural activities. It varies from crop to crop in different geoenvironmental condition. Before the formation of sand splay formation the soil

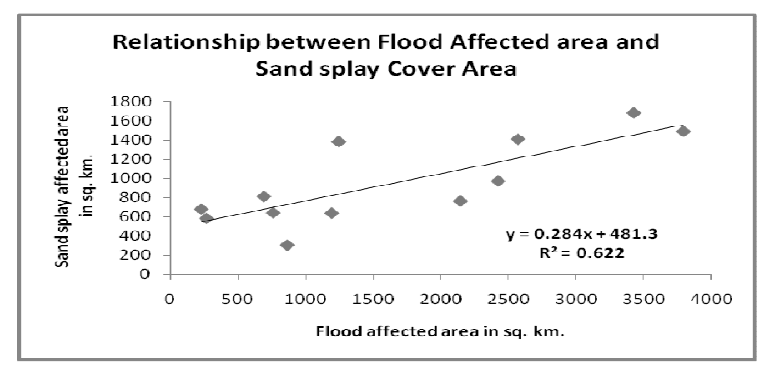

Fig. 12 Flood Affected area and sand splay cover area

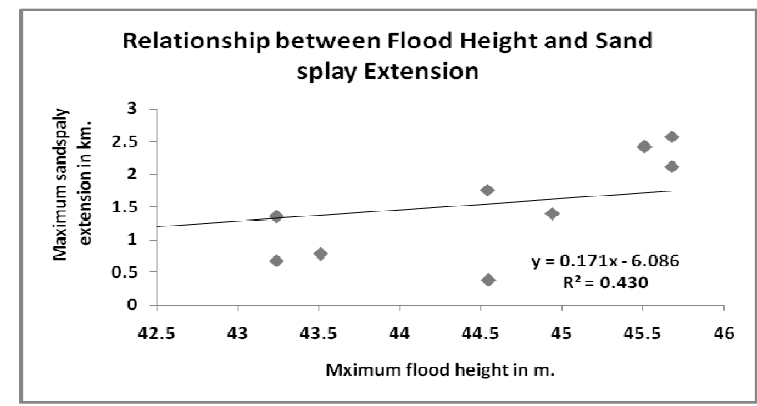

Fig. 13 flood height and sand splay extension 
The areas marginally affected by sand cover, but do not have refused the production entirely, the production quality has reduced in massive scale. On an average productivity of kharif (rice) crop has reduced about 3 to 5 times (Table 7 ). Severe sand cover areas today totally out of production.

\section{Degradation of Soil Quality}

Standard soil quality is one of the important parameter for agricultural activities. It varies from crop to crop in different geoenvironmental condition. Before the formation of sand splay formation the soil quality was very much amicable for the production of paddy, vegetables etc. but after the coverage of sand splay, that suitable soil condition has abruptly degraded. Some essential macro soil quality for crop cultivation like $\mathrm{P}^{\mathrm{H}}, \mathrm{N}_{2}, \mathrm{P}_{2} \mathrm{O}_{5}$, $\mathrm{K}_{2} \mathrm{O}$ etc. has changed for a great extent, which is withstanding against healthy production of crops. $\mathrm{N}_{2}, \mathrm{P}_{2} \mathrm{O}_{5}, \mathrm{~K}_{2} \mathrm{O}$ etc. have reduced in such a scale these are far below the expected threshold limit for good production. $\mathrm{N}_{2}$ has reduced about 5 to 10 times; $\mathrm{P}_{2} \mathrm{O}_{5}$ has lowered down about 15 to 25 times and $\mathrm{K}_{2} \mathrm{O}$ about 3 to 5 times (Table8). So soil quality has degraded in such a pattern that existing paddy dominated crop culture is highly hampered.

\section{Change of Occupation Structure}

Most of the people in the Lower Ajoy River Basin were largely dependent on agricultural activities for their life and livelihood. But in the places where the extent of sand splay is excessively high, agricultural land has thickly covered by sand and has under gone into massive sterility against production there the rural people who were engaged into agricultural sector have forced to shift in other occupation like missioners, daily day labour, retail business etc. In fact, the newly emerged sand splay land may be considered as the principal responsible for shifting of population from cultivator to agricultural labourer, big farmer to marginal farmer, primary worker to marginal secondary workers etc. But the agricultural oustees are not in well and peace at all.

\section{Sand Splay Alleviation Measures}

Sand splay is newly growing quasigeomorphic hazard caused by human being for taming the river flow. Lofty embankments along the river are considered as the prime cause of such disaster So immediate step should be taken to resist this problem in very childhood. For this both structural and nonstructural measures can be adopted.

\section{Structural Measures}

Embankment should be broad based and narrow apex and should be stair stepped. It will help to soak and reduce the striking force of flood discharge. The arc of the embankment should be caged right from the base, because these places get maximum corrosive force from rushing discharge. These steps will help to reduce the tendency of embankment breaching. Sensitive places of the embankment should be surfaced and concretized to save it from sudden breaching. The places already affected by sand splay, phase wise sand removal programs should be activated. The quality sand could be served to the brick clin factory, households who are willing to construct concrete houses. Government, agricultural landholders and the consumers of the sand can share the cost.

\section{Non-structural Measure}

Instead of the remove of sand heap, existing land should be taken into cultivation programs either mixing of required biofertilizers and chemicals.According to the thickness of sand, new crop charts should be prepared. Over sand splay it is quite impossible to cultivate paddy for the first time but there are many crops like watermelon, cucumber, vegetables etc. those can be cultivated normally on those region. The following proposed crop chart for different sand splay thickness zone would give the detail cropping guidelines. For minor change of sand splay texture, spraying of soil from outsides could be done. It will help to raise the level of soil cultivability.

\section{Conclusion}

The flood situation and its way of lateral extension and inundation being performed in such a manner that the flood plain dwellers have nothing to do against flood. The present alleviation measures like the increase of height of embankment, repairing of embankment, aforestation in the upper catchment for checking soil erosion etc adapted by the local government become turns into failure and seems to be the false security to the bank dwellers. Structural measures are very expensive and time-consuming policies. So new solutions may increasingly 
acknowledge the indigenous, traditional and innovative strategies to cope with floods, like flood tolerant houses and crops (Kundzewicz, 2000). Provision of adequate and unhindered natural drainage of the flood plain is mandatory for the upkeep of the ecology and health of the flood plains. This should be made possible by improving, restoring and increasing the number of waterways for the quick and

\section{References:}

Kundzewicz, Z.W. (2000), Coping with Hydrological Extremes, Water International, 25(1), 67-75.

Majumdar, S.C. (1941), Rivers of Bengal Delta, Department of Irrigation and waterways, Govt. of West Bengal

Mukherjee, M (2003), Flood and Land Degradation - A study in the Lower Ajoy Basin. Land Degradation and Desertification (Ed). Rawat Publication, India, pp 374 - 381.

Mukhoopadhyay, S. and Mukherjee, M (2005), Hydrological Characteristics of Flood: A study efficient passage of floodwater as well as making available all natural flood storage on the flood plains. So in fine it may be suggested that to keep a healthy environmental aspect of the flood plain the behavioral adjustment of flood plain dwellers should be changed as well as the policy makers and administrator should think for alternative policies in flood reduction and management.

in the lower Ajoy river. River Floods: A Socio technical Approach. ACB Publications. pp 5158.

Pearce, F. (2001): Dams and floods. WWF International Research Paper, www.relief Web.int

Saha, M.N. (1935), Collected works of M.N.Saha,Vol.I, University of Calcutta, India.

William, W (1930), Lectures on the Ancient System of Irrigation in Bengal, University of Calcutta. India

Table 1: Land use pattern in Lower Ajoy River Basin

\begin{tabular}{|l|l|l|}
\hline Land use category & Area (hectare) & $\begin{array}{c}\text { \% to total } \\
\text { areas }\end{array}$ \\
\hline Irrigated land & 113431.66 & 40.27 \\
\hline Unirrigated land & 62852.24 & 22.31 \\
\hline Forest & 37115.44 & 13.17 \\
\hline Uncultivable land & 63294.78 & 22.48 \\
\hline Cultivated waste & 4971.73 & 1.77 \\
\hline
\end{tabular}

Source: District Census Hand book, 2001,\& Economic Review, West Bengal, 2009,Govt. of W. Bengal.

Table 2: Flood and sand splay affected area in different years

\begin{tabular}{|l|l|l|l|l|l|l|l|}
\hline Year & $\begin{array}{l}\text { Affected } \\
\text { areas } \\
\text { in sq. } \\
\text { km. }\end{array}$ & $\begin{array}{l}\text { \% to } \\
\text { total } \\
\text { area }\end{array}$ & \multicolumn{2}{|c|}{\begin{tabular}{l}
\multicolumn{2}{|c|}{ Affected No. of Mouzas } & $\begin{array}{l}\text { Extent of } \\
\text { sand splay } \\
\text { in } \\
\text { hectares }\end{array}$ & $\begin{array}{l}\text { Entirely } \\
\text { affected }\end{array}$ & $\begin{array}{l}\text { Partially } \\
\text { Saffected }\end{array}$ & Totansion of \\
Siver embankment \\
(distance in km.)
\end{tabular}} \\
\hline 1956 & 680.00 & 24.14 & 153 & 32 & 185 & 231.45 & 0.38 \\
\hline 1959 & 584.34 & 20.74 & 120 & 27 & 147 & 269.63 & 0.38 \\
\hline 1970 & 812.24 & 28.83 & 186 & 36 & 222 & 693.48 & 0.47 \\
\hline 1971 & 642.71 & 22.81 & 130 & 31 & 161 & 762.11 & 0.78 \\
\hline 1973 & 639.02 & 22.68 & 124 & 36 & 160 & 1193.20 & 1.12 \\
\hline 1978 & 1680 & 59.64 & 307 & 67 & 374 & 3421.32 & 2.42 \\
\hline 1984 & 305.72 & 10.85 & 78 & 20 & 98 & 865.55 & 0.68 \\
\hline 1995 & 1380.82 & 48.99 & 227 & 49 & 276 & 1245.67 & 1.40 \\
\hline 1999 & 1408 & 49.98 & 237 & 60 & 297 & 2567.23 & 2.12 \\
\hline 2000 & 1488 & 52.82 & 263 & 106 & 369 & 3788.25 & 2.57 \\
\hline 2006 & 764.23 & 27.12 & 152 & 46 & 198 & 2143.56 & 1.35 \\
\hline 2007 & 972.79 & 34.53 & 214 & 79 & 293 & 2421.57 & 1.76 \\
\hline
\end{tabular}

Source: Department of Irrigation and Water Ways, Govt. of West Bengal. 
Table 3: Highest flood level in different gauge stations.

\begin{tabular}{|c|c|c|c|c|c|c|c|c|c|c|c|c|c|}
\hline $\begin{array}{l}\text { Gauge } \\
\text { Station }\end{array}$ & $\begin{array}{l}\text { DL (m.) } \\
\text { EDL (m.) }\end{array}$ & 1956 & 1959 & 1970 & 1971 & 1973 & 1978 & 1984 & 1995 & 1999 & 2000 & 2006 & 2007 \\
\hline Beta & $\begin{array}{l}57.90 \\
58.90\end{array}$ & 61.05 & N.S & N.S & 59.06 & N.S & 61.14 & 58.83 & 59.75 & 60.70 & 61.50 & 58.70 & 60.65 \\
\hline Satkakonia & $\begin{array}{l}51.75 \\
52.75\end{array}$ & 54.41 & N.S & 53.50 & 53.10 & 53.48 & 55.44 & 53.39 & 54.42 & 54.68 & 54.90 & 53.38 & 53.84 \\
\hline Maliara & $\begin{array}{l}41.70 \\
42.70\end{array}$ & 45.37 & 45.58 & 44.17 & 44.47 & 43.16 & 45.71 & 43.28 & 45.72 & 44.46 & 45.86 & 43.42 & 44.28 \\
\hline Gheropara & $\begin{array}{l}39.41 \\
40.41\end{array}$ & 40.89 & 41.31 & 40.51 & 40.29 & 40.63 & 42.82 & 39.02 & 42.50 & 43.25 & 42.97 & 40.22 & 42.60 \\
\hline Natunhat & $\begin{array}{l}19.19 \\
20.19\end{array}$ & 21.02 & 21.84 & 20.40 & 20.62 & 20.00 & 22.42 & 21.70 & 22.30 & 22.89 & 23.21 & 20.49 & 21.37 \\
\hline Total & & 44.548 & 36.24 & $\begin{array}{l}39.64 \\
5\end{array}$ & $\begin{array}{l}43.50 \\
8\end{array}$ & $\begin{array}{l}39.31 \\
7\end{array}$ & $\begin{array}{l}45.50 \\
6\end{array}$ & $\begin{array}{l}43.24 \\
4\end{array}$ & $\begin{array}{l}44.93 \\
8\end{array}$ & $\begin{array}{l}45.19 \\
6\end{array}$ & $\begin{array}{l}45.68 \\
8\end{array}$ & $\begin{array}{l}43.24 \\
2\end{array}$ & $\begin{array}{l}44.54 \\
8\end{array}$ \\
\hline
\end{tabular}

Source: Irrigation and Waterways Directorate, Mayurakshi S. Canal Division,Govt. of W.Bengal. N.S.= No Spill.

Table 4: Month wise flow level in different gauge satiations in monsoon season (June to October)

\begin{tabular}{|c|c|c|c|c|c|c|c|c|c|c|c|c|c|c|c|}
\hline \multirow[t]{2}{*}{ Year } & \multicolumn{5}{|c|}{ Station Maliara } & \multicolumn{5}{|c|}{ Station Gheropara } & \multicolumn{5}{|c|}{ Station Natunhat } \\
\hline & June & July & Aug. & Sept. & Oct. & June & July & Aug. & Sept. & Oct. & June & July & Aug. & Sept. & Oct. \\
\hline 1956 & 40.61 & 41.90 & 42.00 & 45.37 & 41.28 & 36.50 & 37.20 & 38.40 & 40.89 & 39.10 & 17.60 & 18.81 & 19.60 & 21.02 & 20.96 \\
\hline 1959 & 40.21 & 43.22 & 43.52 & 44.38 & 45.58 & 37.71 & 38.21 & 39.80 & 41.39 & 38.80 & 18.10 & 18.90 & 19.85 & 21.18 & 21.84 \\
\hline 1970 & 42.00 & 42.45 & 41.75 & 44.17 & 42.09 & 37.23 & 39.10 & 36.40 & 40.51 & 39.20 & 17.12 & 17.92 & 18.92 & 20.40 & 20.12 \\
\hline 1971 & 39.90 & 44.08 & 44.46 & 44.47 & 43.19 & 36.42 & 37.92 & 38.60 & 40.29 & 37.80 & 17.42 & 18.81 & 19.75 & 20.62 & 19.78 \\
\hline 1973 & NA & 42.60 & 43.16 & 43.10 & NA & 36.81 & 38.82 & 37.21 & 40.63 & 38.50 & 17.91 & 19.42 & 21.00 & 21.67 & 19,91 \\
\hline 1978 & 43.60 & 42.15 & 42.24 & 45.71 & 43.28 & 38.81 & 37.50 & 39.95 & 42.82 & 39.70 & 18.60 & 17.90 & 19.01 & 22.42 & 21.30 \\
\hline 1984 & 39.70 & 41.75 & 43.18 & 42.91 & 43.28 & 38.40 & 38.21 & 39.02 & 37.50 & 37.45 & 18.19 & 19.70 & 21.60 & 21.70 & 21.88 \\
\hline 1999 & 40.50 & 40.82 & 41.58 & 40.40 & 38.40 & 36.00 & 37.17 & 38.00 & 43.25 & 39.59 & 17.51 & 18.12 & 19.65 & 22.89 & 19.10 \\
\hline 2000 & 40.60 & 42.10 & 42.20 & 45.86 & 39.30 & 36.54 & 38.78 & 35.96 & 40.97 & 37.00 & 16.80 & 17.61 & 19.18 & 23.21 & 18.61 \\
\hline 2007 & 40.21 & 42.34 & 42.76 & 43.27 & 39.40 & 37.23 & 38.90 & 37.58 & 37.80 & 38.23 & 17.67 & 17.90 & 19.34 & 22.56 & 20.42 \\
\hline
\end{tabular}

Source: Irrigation and Waterways Directorate, Mayurakshi South Canal Division, Govt. of West Bengal.

Table 5: Sand splay distribution in two banks of the river

\begin{tabular}{|c|c|c|c|c|c|c|c|}
\hline \multirow[t]{2}{*}{ Year } & \multicolumn{2}{|c|}{$\begin{array}{c}\text { Cumulative no. of sand } \\
\text { splay }\end{array}$} & \multirow{2}{*}{$\begin{array}{c}\text { Cumulative } \\
\text { total } \\
\text { number }\end{array}$} & \multicolumn{2}{|c|}{ Area of sand splay in hectare } & \multirow[t]{2}{*}{$\begin{array}{l}\text { Total area in } \\
\text { hectare }\end{array}$} & \multirow[t]{2}{*}{$\begin{array}{l}\text { Newly affected } \\
\text { area in hectare }\end{array}$} \\
\hline & Left bank & Right bank & & Left bank & Right bank & & \\
\hline 1956 & 2 & 3 & 5 & 102.20 & 119.25 & 231.45 & - \\
\hline 1959 & 3 & 5 & 8 & 133.42 & 136.21 & 269.63 & 65.67 \\
\hline 1970 & 5 & 7 & 12 & 248.76 & 444.72 & 693.48 & 143.43 \\
\hline 1971 & 6 & 9 & 15 & 368.93 & 393.18 & 762.11 & 165.32 \\
\hline 1973 & 6 & 11 & 16 & 497.66 & 695.54 & 1193.20 & 347.86 \\
\hline 1978 & 9 & 18 & 27 & 1432.32 & 1989 & 3421.32 & 1054.63 \\
\hline 1984 & 9 & 18 & 27 & 335.23 & 530.3 & 865.55 & 89.64 \\
\hline 1995 & 10 & 19 & 29 & 643.27 & 602.4 & 1245.67 & 245.68 \\
\hline 1999 & 10 & 24 & 34 & 1097.74 & 1469.49 & 2567.23 & 1465.31 \\
\hline 2000 & 15 & 32 & 47 & 1478.98 & 2309.29 & 3788.25 & 1678.90 \\
\hline 2006 & 17 & 32 & 49 & 1087.67 & 1055.89 & 2143.56 & 891.34 \\
\hline 2007 & 19 & 34 & 53 & 1165.88 & 1255.69 & 2421.57 & 876.21 \\
\hline
\end{tabular}

Source: Department of Irrigation and Water Ways and Questionnaire survey 
Table 6: Area of sand splay laden cultivated land

\begin{tabular}{|c|c|c|c|c|}
\hline Name of the Mouza & Name of the Block & $\begin{array}{c}\text { Total amount of } \\
\text { cultivated land in } \\
\text { hectare }\end{array}$ & $\begin{array}{l}\text { Loss of cultivated } \\
\text { land in hectare }\end{array}$ & $\begin{array}{c}\% \text { to total } \\
\text { cultivated land }\end{array}$ \\
\hline Bhedia & \multirow{4}{*}{ Ausgram } & 335.00 & 61.66 & 18.40 \\
\hline Bramhan Dihi & & 164,00 & 21.66 & 13.20 \\
\hline Maloncha & & 303.46 & 15.67 & 5.16 \\
\hline Malaria & & 286.90 & 28.68 & 9.99 \\
\hline Basudha & Kanksa & 593.47 & 140 & 23.59 \\
\hline Gitgram & \multirow{5}{*}{ Bolpur } & 110 & 30.80 & 28.00 \\
\hline Natungram & & 90 & 40.20 & 44.66 \\
\hline Rasulpur & & 110 & 40.20 & 36.54 \\
\hline Haripur & & 60 & 40.60 & 67,66 \\
\hline Ghidaha & & 80.93 & 25 & 30.89 \\
\hline Nabagram & \multirow[t]{2}{*}{ Mongolkot } & 66.60 & 20.45 & 30.70 \\
\hline Nathunhat & & 106 & 25.43 & 23.99 \\
\hline Bira & \multirow{3}{*}{ Ketugram } & 46 & 18.78 & 40.82 \\
\hline Bankai & & 44 & 10.64 & 26.60 \\
\hline Narenga & & 75 & 22.38 & 29.84 \\
\hline Srikrishnapur & \multirow[t]{5}{*}{ Nanur } & 130 & 80.50 & 61.92 \\
\hline Husainpur & & 180 & 30 & 16.66 \\
\hline Vepura & & 50 & 20 & 40.00 \\
\hline Gangnara & & 42 & 15.50 & 36.90 \\
\hline Gomra & & 170 & 12 & 7.05 \\
\hline & Total & 3043.36 & 700.15 & 23.01 \\
\hline
\end{tabular}

Source: Birbhum and Burdwan Zila Parishad, Govt. of West Bengal ,2008-09.

Table 7: Average Production of kharif (Rice) crop (kg./ha.)

\begin{tabular}{|l|l|l|l|l|l|}
\hline \multirow{2}{*}{$\begin{array}{l}\text { Name of the } \\
\text { Mouza }\end{array}$} & $\begin{array}{c}\text { Production } \\
\text { before sand } \\
\text { splay }\end{array}$ & \multicolumn{2}{|c|}{$\begin{array}{c}\text { Production in } \\
\text { marginal sand splay } \\
\text { area }\end{array}$} & \multicolumn{2}{|c|}{$\begin{array}{c}\text { Production in severe sand } \\
\text { splay area }\end{array}$} \\
\cline { 3 - 6 } & & $\begin{array}{l}\text { Absolute } \\
\text { area }\end{array}$ & In \% & $\begin{array}{l}\text { Absolute } \\
\text { area }\end{array}$ & In \% \\
\hline Bhedia & 3750 & 1500 & 40.00 & Nil & 100 \\
\hline Natungram & 4000 & 750 & 18.75 & Nil & 100 \\
\hline Maliara & 3000 & 800 & 26.66 & Nil & 100 \\
\hline Srikrishnapur & 4500 & 1500 & 33.33 & Nil & 100 \\
\hline Narenga & 3600 & 1312.50 & 36.45 & Nil & 100 \\
\hline Gomra & 3375 & 500 & 14.81 & Nil & 100 \\
\hline Average & $\mathbf{3 7 0 4 . 1 6}$ & $\mathbf{1 0 6 0 . 4 1}$ & $\mathbf{2 8 . 6 2}$ & Nil & $\mathbf{1 0 0}$ \\
\hline
\end{tabular}

Source: Village level survey and cluster survey.

Table 8: Soil status report before and after sand splay

\begin{tabular}{|l|l|l|l|l|l|l|l|l|}
\hline \multirow{2}{*}{ Name of the places } & \multicolumn{2}{|c|}{$\mathbf{P}^{\mathbf{H}}$} & \multicolumn{2}{c|}{$\mathbf{N}_{\mathbf{2}}$ (kg./ha) } & \multicolumn{2}{c|}{$\mathbf{P}_{\mathbf{2}} \mathbf{O}_{\mathbf{5}}$ (kg./ha.) } & \multicolumn{2}{c|}{$\mathbf{K}_{2} \mathbf{O}(\mathbf{k g} . / \mathbf{h a}$.) } \\
\cline { 2 - 11 } & Before & After & Before & After & Before & After & Before & After \\
\hline Natungram & 6.6 & 7.5 & 200 & 49.5 & 90 & 7.9 & 294 & 46 \\
\hline Gitgram & 7.0 & 7.3 & 250 & 30.5 & 85 & 4.2 & 240 & 65 \\
\hline Maliara & 7.1 & 7.1 & 280 & 39.0 & 21.2 & 4.2 & 316 & 59 \\
\hline Bhedia & 6.9 & 7.1 & 330 & 26.4 & 45.50 & 3.6 & 305 & 72 \\
\hline Srikrishnapur & 7.0 & 8.2 & 300 & 35.0 & 70.00 & 5.5 & 220 & 70 \\
\hline
\end{tabular}

Source: Technical Report: Vol. 7, Department of Soil Science, Palli Siksha Bhavana, Visv-Bharati University.

Table 9: Proposal of Cropping Chart in Sand Splay Area:

Table 9: Proposal of Cropping Chart in Sand Splay Area:
\begin{tabular}{|l|l|}
\hline $\begin{array}{l}\text { Depth of sand in } \\
\text { cm. }\end{array}$ & Nature of farming \\
\hline $\mathbf{1 5}$ to 25 & $\begin{array}{l}\text { Adding organic manure, farm yard manure, introduced root crops like potato, beet, carrot, tomato, in the post kharif } \\
\text { season. Crops like pumpkin, cucumber, watermelon, creeper like vegetables etc. also could be introduced. }\end{array}$ \\
\hline $\mathbf{2 5}$ to 45 & $\begin{array}{l}\text { Kharif dhancha (kind of fuel stick), or green manure like sun hemp, karang etc. during kharif season etc. should be } \\
\text { cultivated. }\end{array}$ \\
\hline $\mathbf{4 5}$ to $\mathbf{6 0}$ & $\begin{array}{l}\text { It is suitable for agro forestry, by digging } 45 \mathrm{~cm} \text {. diameter for multipurpose trees like subabul (acacia), neem, sisu , } \\
\text { cashew nut etc. Surface to be planted by black and green gram after one year }\end{array}$ \\
\hline$>\mathbf{6 0}$ & Various wild grooves forage crops, like dinanath, paspalam dilatanum, and Chinese cabbages etc. can be planted. \\
\hline
\end{tabular}

Source: Mukherjee, M. (Ed.), Debacle, Kolkata, vol. vi. 